\section{The democratic peace proposition: an agenda for critical analysis}

\section{Steve Chan}

$\mathrm{T}$

he proposition that democracies are more peaceful than nondemocracies in their international relations has gained a great deal of attention in academic as well as policy circles. Among scholars of international relations, this topic has arguably been the most popular subject of analysis in recent years. Its popularity reflects the considerable amount of empirical evidence pointing to an absence of war between democracies. Commenting on the democratic peace proposition, one scholar suggested that it came "as close as anything we have to an empirical law in international relations." ${ }^{1}$ Echoing the same sentiment, another remarked that this phenomenon represented "one of the strongest nontrivial or nontautological generalization that can be made about international relations." ${ }^{2}$ Among policymakers, U.S. President Bill Clinton propounded “democratic enlargement” to promote global peace. His successor, President George W. Bush, justified the invasion of Iraq in part on the grounds of introducing democracy to Iraq and the Middle East more generally, with the intent thereby of making this region more stable and peaceful.

The discourse on democratic

The proposition that democracies are more peaceful than nondemocracies in their international relations has gained a great deal of attention in academic and policy circles. But is the proposition wholly warranted? This essay raises some conceptual, methodological, and causal difficulties of the proposition and points to resulting policy issues. international liberalism, ${ }^{3}$ with its intellectual origin traced to U.S. President Woodrow Wilson and even the German philosopher Immanuel Kant. ${ }^{4}$ It has encountered skeptical reaction from those adhering to the realist tradition. The realists argue that all states are compelled by the structure of international relations to pursue power and seek survival..$^{5}$ This systemic pressure, according to realists, implies that all states regardless of their regime characteristics (that is, regardless of whether they have a democratic or autocratic regime) are likely to behave similarly.

This essay pursues a different tack. In the spirit of constructive criticism, it takes on the literature on democratic peace on its own terms. This literature has been characterized primarily by statistical analyses using large datasets on states' regime characteristics and their conflict behavior. The intent is to suggest fruitful areas for further research in order to clarify, confirm, and extend the democratic peace proposition. It is not to undertake a comprehensive review of the relevant literature consisting of dozens of books and hundreds of articles, ${ }^{6}$ but rather to point out areas of conceptual confusion and problematic inference that require attention. The remainder of this essay is organized into four sections, addressing, respectively, (1) conceptual, (2) methodological, (3) causal, and (4) policy issues pertaining to the democratic peace proposition.

\section{Conceptual confusion}

It is natural to begin by asking which ideas analysts have in mind when they speak of democracy and peace. Depending on one's conceptualization and operationalization of these terms, the democratic peace proposition can mean very different things. When one goes back to the supposed intellectual origins of this proposition, one is confronted with a discrepancy whereby popular sovereignty or majority rule was not necessarily the predominant characteristic hypothesized to cause a regime's peaceful orientation.

For instance, Immanuel Kant spoke of Rechtstaat and emphasized the ideas of republicanism and rule of law in his treatise on "perpetual peace."7 A constitutional monarchy, such as that of the U.K., can offer an example par excellence for the rule of law - defined by the existence of an impartial and independent judiciary, legal transparency and equality, and respect for due process - but it is clearly not a republic. Conversely, Bismarkian Prussia as well as contemporary Singapore can exemplify the "administrative state," even though they may not quite meet some people's criterion of electoral competition and popular representation.

Some analysts have also correctly pointed out that Kant did not quite have popular rule in mind when he wrote about a possible relationship between a regime's characteristics and its foreign conduct. ${ }^{8}$ Libertarianism rather than popular rule was a more important consideration for him and others. By libertarianism, one usually means personal freedom and individual liberty, such as the right to free expression and assembly. Yet public debate continues about whether abortion, divorce, or samesex marriages are a matter of personal rights. Some countries restricted these rights until the recent past, and others continue to do so. There is clearly considerable historical variation even among the established democracies - and within these countries in the extent to which personal freedoms have been accorded to religious and racial minorities.

Naturally, libertarianism and popular rule do not always go hand in hand such that Victorian Britain and contemporary Hong Kong offer considerable personal liberties although not universal suffrage required for popular rule. A question arises, however, when some definition of libertarianism includes the right to private property and institutions of free enterprise. ${ }^{9}$ On this dimension, Hong Kong can be rated more liberal than Britain and France (which have public enterprises), not to mention all the socialist states. With the adoption of a capitalist economy, countries such as China, 
Russia, and Vietnam would presumably receive higher scores on this dimension even though democracy and capitalism are not synonymous in most people's mind.

Still, a different and presumably relevant definition of democracy, as alluded to already, can emphasize universal adult suffrage, electoral competition, alternation of power, and especially majority rule. These considerations would call into question much of the extant analyses that defined the United States, the United Kingdom, and other European countries as democracies before 1914 because except for four countries, female suffrage — not to mention actual voting rights for African Americans - was not instituted well afterwards. Moreover, one may well question the extent of electoral competition and political turnover for countries that have been (subjectively) rated as democracies, but ones that have had long stretches of singleparty rule (Japan, Mexico, Italy, India, and even Sweden). At the same time, if majority rule is the defining character of democracy, Britain, Australia, New Zealand, and most recently, the United States (when Al Gore lost to George W. Bush) have all seen the election of a candidate or party which received fewer popular votes than its opposition. Conversely, current regimes in Venezuela, Iran, and the Palestinian territories (the Hamas) have been elected and arguably represent popular rule. Finally, peaceful regime changes or turnover of the office of the chief executive between the leaders of competing political parties has been suggested to offer another distinctive mark of a democracy. ${ }^{10}$ The extent of such alteration or alternation, however, can be a matter of some controversy and naturally pertains to arguments about, for example, whether the August 2008 war between Russia and Georgia indicates any implications for the democratic peace proposition.

Much of the quantitative literature on democratic peace has relied on the Polity dataset, specifically on composite scores tallying disparate indicators such as constraints on executive power, competitiveness in selecting the chief executive, and openness of this process. The coders of this dataset rated (subjectively) each of the latter dimensions, and these individual ratings are usually summed by analysts to produce an aggregate measure of a country’s "democraticness” or "autocraticness.” This practice can often conceal more than reveal important differences, ${ }^{11}$ because the same aggregate score can reflect very different underlying traits. It is as if a physician simply looks at a patient's body weight without considering this person's age, gender and physical stature (e.g., a short, fat person compared to a tall, thin person). As for the Freedom House's rating of freedom in different countries, another popular source of data, it is worthwhile to check whether more objective indicators of democracy, such as those offered by Vanhanen, ${ }^{12}$ would produce convergent empirical results. Some scholars have sought to integrate different dimensions of democracy from several datasets in order to develop a more appropriate measure of this concept. ${ }^{13}$

Turning to the "dependent variable," one may ask whether one can study "peace” by counting the frequency of militarized interstate disputes. Recent work on the democratic peace proposition has focused overwhelmingly on these disputes rather than the occurrence of war per se. Significantly, other types of foreign conduct - such as covert subversion, economic sanction, and military intervention - are not necessarily reflected by the frequency count of militarized disputes. ${ }^{14}$ Moreover, when a small country — say, Grenada, Panama, the Dominican Republic — is quickly overwhelmed in a military confrontation with a big country, battle fatalities never reach the 1,000 threshold of combat casualty customarily required for defining a war. Does this mean that a "war" did not happen, or just that due to the power disparity between the contestants, the weak was quickly subdued by the strong? Such "nonwars" reflect more the strength of the powerful than its peaceful disposition.

Significantly, the definition of militarized disputes and interstate wars used by most quantitative researchers of the democratic peace proposition systematically biases the results because it rules out from their analyses so-called extra-systemic conflicts. They are extra-systemic because, before the formation of the United Nations, in order to be recognized as a member of the interstate system, a regime must be diplomatically recognized by Britain and France in particular. Accordingly, all the imperial and colonial wars waged by these two "democratic" countries in the nineteenth century would not count against the monadic version of the democratic peace proposition because the other side of these conflicts did not technically qualify for statehood. ${ }^{15}$

Finally, should peace be defined simply as the absence of militarized disputes or of war? Should one consider a definition of "positive peace" that includes human well-being as well as a state's internal social conditions? Such a conception of peace offers a very different approach to conflict study. The Global Peace Index exemplifies this alternative vision and, if adopted by researchers of democratic peace, is likely to produce considerably different empirical patterns from those reported by the current literature. ${ }^{16}$

\section{Methodological concerns}

Wars are rare events - whether they are undertaken by democracies or autocracies. Indeed, there appears to be an "autocratic peace" in addition to "democratic peace."17 On top of the analytic challenge introduced by this rarity, causal attribution of a state's peaceful foreign conduct to its democratic regime is complicated by the problem of multicollinearity. Democracy tends to be statistically associated with other socioeconomic and international variables, such as a country's wealth and industrial development, its alliance portfolio, its involvement in foreign trade and interstate organizations, and its status as a former colony. This multicollinearity invariably confounds attempts to discriminate among the influence of various candidate (independent) variables on a country's propensity to get into militarized disputes or wars. It is therefore not surprising that some scholars have questioned whether the democratic peace proposition is spurious and have suggested that shared capitalism, U.S. hegemony, or settled borders are actually responsible for the observed association. ${ }^{18}$ Others have pointed out that the relationship between democracy and 
peace is a two-way street. Whereas democracy may promote peace, countries located in a peaceful region (e.g., Scandinavia) are more likely to develop democratic institutions in the first place. $^{19}$

Temporal and spatial interdependencies are another source of concern. ${ }^{20}$ How helpful, or valid, is it to treat World War I, say, as dozens of bilateral conflicts (each taken to represent a separate independent observation), so that one records it as separate wars between Britain and Germany, France and Germany, Russia and Germany, and Belgium and Germany, and so on and so forth? This treatment seems to fly in the face of our historical knowledge. We know that Britain went to war against Germany because Germany had invaded Belgium, and that German invasion of Belgium (the Schlieffen plan) had something to do with Berlin's concern about fighting a two-front war against France and Russia simultaneously. And, of course, the initial impetus for the war in August 1914 came from a dispute between Serbia (a Russian ally) and Austria-Hungary (a German ally). There was therefore diffusion of conflict across borders, causing a chain effect that brought these belligerents to a military showdown.

There is also temporal dependency to consider. Some historians have viewed World War I and World War II as a continuous conflict with but a short interval of peace. Similarly, one can plausibly argue that the genesis of the U.S. and U.K. invasion of Iraq in 2003 can be traced back to the First Gulf War in 1989 when these countries and others confronted Baghdad over its invasion of Kuwait. As most dyads manage to avoid disputes year after year and because some conflicts' recurrences are interrelated, could the democratic peace phenomenon be shown to exist only because the same observations are compounded over and over? ${ }^{21}$

It is also pertinent to ask whether these observations have been compounded by the inclusion of marginal actors in the analysis and treating them as if they are equivalent to the major characters. For instance, does it make sense to give equal weight to the United States and Germany as a conflict dyad in World War II as to Brazil and Germany and to the USSR and Japan (the Soviet Union did not declare war on Japan until a few days before Japan's surrender)? Surely, these observations refer to very different substantive phenomena. Some (e.g., Brazil, Burma, Bolivia) are bit characters while others are major belligerents. Some states' participation in the war was minor and even only symbolic, whereas it involved a major undertaking for others. To take another example, it would be quite implausible for Poland, Georgia, or even Britain to join the "coalition of the willing" independent of a U.S. decision to invade Iraq. Similarly, Belgium, Greece, Colombia, and Turkey would hardly have fought in the Korean War had it not been for the U.S. intervention in this conflict. It seems important to distinguish these "apples" and "oranges" rather than simply lumping them as "fruits.” The purchase of a larger number of observations may come at the expense of analytic precision and conceptual clarity.

\section{Causal attributions}

Space does not allow a full discussion of the various explanations that have been advanced for the democratic peace proposition. One especially cogent explanation, however, focuses on audience costs and popular sanction. ${ }^{22}$ The basic idea is that democratic leaders will suffer negative political consequences if they fail to honor their declared policies (or if they encounter policy failures). Voters, the media, and the political opposition will punish them for this behavior. Therefore, democratic leaders face greater domestic audience costs - a tendency that in turn implies that when these leaders do make foreign policy threats, these threats are more credible. The logic of this implication, however, suggests that this greater credibility on the part of democratic leaders would incline authoritarian leaders to be more disposed to back down from a confrontation with them. As well, because authoritarian leaders do not face the same prospect of a domestic backlash as the democratic leaders, their threats are inherently less credible. They are more likely to be "pushed around" because they would not suffer the same domestic consequences if they renege on their policy or suffer foreign policy setback. ${ }^{23}$ It points to authoritarian leaders' concessions as a reason why confrontations are sometimes avoided. ${ }^{24}$ Note also that the attribution of domestic audience costs simply argues that democratic leaders are more prudent about taking on foreign conflicts due to their concerns about adverse domestic repercussions. It does not claim that these leaders are necessarily more peaceful in their disposition, only that they are more risk averse and require a higher threshold of expected success before they start a militarized dispute or go to war.

Another explanation of the democratic peace proposition focuses on structural or institutional features, specifically the fact that in democracies power is not concentrated in the hands of one person or institution. This sharing of power and the existence of many veto and oversight groups suggest that democracies must build a strong consensus before going to war. Some scholars have questioned how well institutional checks and balances have worked in the lead up to the U.S. invasion of Iraq. An assertive executive, an acquiescent legislature, uncritical media, and a generally passive public raise concerns about the institutional restraints on democracies' decision to start war (as opposed to fighting back after being attacked such as in the wake of Pearl Harbor).$^{25}$ Significantly, at least some of the hypothesized institutional mechanisms that are supposed to foster responsible government and checks against a rush to war are peculiar to specific democracies. For instance, in parliamentary systems the distinction between executive and legislative branches is irrelevant. Similarly, to the extent that opposition parties can serve as a watchdog, it is important to recognize differences among countries that have one dominant party, two competitive parties, and multiparty competition and coalition governments. The differentiation of these different types of democratic systems and the study of their different propensity to undertake war is a fruitful area for future research. ${ }^{26}$ Note again that the institutional explanation of democratic peace simply argues that democratic 
leaders face more domestic constraints in order to take their country to war; it does not claim that these leaders are inherently less bellicose in their nature.

The argument of institutional constraints naturally raises the question of whether authoritarian leaders may under certain circumstances face constraints not dissimilar from their democratic counterparts. For example, can authoritarian leaders also be punished by their domestic constituents and suffer audience costs if not from the media and voters, then from their political rivals? It is true that democratic leaders are accountable to a larger constituency and therefore more likely to represent the public good. ${ }^{27}$ At the same time, just as not all democracies are alike (e.g., parliamentary versus presidential systems, two-party versus multiparty systems), not all autocracies are alike. Recent research shows that some authoritarian leaders can also suffer from domestic audience costs such as when they do not control their secret police or have exclusive power to make political appointments. ${ }^{28}$ Therefore, more in-depth analysis of specific institutional mechanisms is necessary in order to understand better the propensity of different types of regimes to undertake war.

Yet another explanation of democratic peace has been offered with a focus on the norms and attitudes of democracies' mass public. ${ }^{29}$ It is proposed that people living in democracies have been socialized to share a tolerant and pacific ethos that they extend to their relations with foreign countries, at least other countries that are democratic. This public opinion, however, has not restrained democracies from waging or considering preventive war against others, and even fighting against their own kind (e.g., the American Civil War, the Boer War, the War of American Independence) if one is willing to stretch the concept of democracy and go back in time. In fact, public opinion often rewards leaders for successful bellicosity (the socalled rally-behind-the-flag syndrome). Recent research has taken on the interesting question of whether public opinion turns against a war because of the perceived failure of an administration's policy (such as in Iraq) or the mounting costs (especially casualties) of this endeavor. ${ }^{30}$ Research on public opinion suggests that the American people may be characterized as prudent but hardly pacific. ${ }^{31}$

Naturally, public opinion influences political accountability and official policies when people can cast ballots to express their preference. Electoral institutions and party systems, however, can intervene to impede or distort this expression. ${ }^{32}$ When both major parties in a two-party system agree on a policy - as in Britain and the United States on going to war against Iraq in 2003 — voters may be denied a meaningful choice. Even when most voters are opposed to waging war as in Britain, public opinion may not be enough to restrain an incumbent government. Casting a vote for a minor party is discouraged because of the single-member district, plurality rule, which favors the two dominant parties. Conversely, popular sentiments are more likely to be reflected, and less likely to be distorted, when a country has a multi-member district, proportionate representation of election. Other institutional factors, such as term limitation of the length that an official can serve (the U.S. president is limited to two terms), surely also affect the prospect of audience costs and voter sanction. The U.S. presidential race is usually decided by elections in a few pivotal or battleground states. As a consequence, public opinion in some areas of the country is more salient for candidates than elsewhere. Due to the nature of the Electoral College, voters in some states are accorded more voice than in other states, and this electoral disproportionality tends to favor the more rural and conservative states with a smaller and less diverse population.

Policy implications

Until 2003, the democratic peace proposition has generally been taken to mean that democracies are unlikely to initiate war. This does not mean that democracies will not fight autocracies, but rather that they will not undertake war unless faced with imminent danger and given just cause. ${ }^{33}$ This expectation suggests that democracies will not wage preventive wars when they are not faced with the danger of being attacked, and in violation of international norms recognizing other states' sovereignty and territorial integrity. The Iraq war therefore presents a critical challenge to the democratic peace proposition because it seemingly challenges both the institutional and normative explanations advanced for this proposition. Two leading democratic states, the United States and the United Kingdom, went to war in defiance of international norms and domestic opposition. The hypothesized institutional and normative constraints against initiating war did not appear to have worked or worked with great effect. It also appears that once in war, these democracies have a hard time extricating themselves from a protracted and unpopular conflict.

The Iraq war has increased interest in the debate about whether military intervention can foster democracy abroad. This burgeoning literature shows that the evidence bearing on this question is far from clear or decisive. ${ }^{34}$ By its very nature, this research calls for counterfactual reasoning, posing the question of what would have been the political and economic conditions of a country had foreign intervention not happened. There appears to be some evidence that a hasty attempt to introduce capitalist democracy in a war-torn society can actually have a deleterious, or counterproductive, effect. ${ }^{35}$ Moreover, the pre-existing socioeconomic conditions of the target of intervention would make a significant difference. That Germany and Japan, for example, had had experience with electoral competition at some point in their history prior to the U.S. occupation and that they had had an educated population and an industrial economy before 1945 augured well for their democratic prospects. Conversely, the chances for democracy taking roots in, say, Iraq and Afghanistan are much more problematic.

Recent scholarship has offered in-depth historical analysis of the preventive motivation. It has shown that democratic leaders are quite capable of contemplating the possibility of starting a preventive war. ${ }^{36}$ Israel launched attacks against Iraqi and Syrian nuclear facilities, and the United States came very close to launching similar attacks against North Korea, China, and Cuba (against the Soviet missiles placed on 
that island during the Cuban Missile Crisis). Similarly, Britain and France considered joint action against the looming threat from Nazi Germany in the 1930s. This and other actions did not come to pass but these "near misses" should not be counted as positive evidence for the democratic peace proposition.

More generally, the democratic peace proposition argues that democracy contributes to peace but it does not claim that democracy is the only approach to peace. Peace can be established by a variety of ways, including imperial rule and nuclear deterrence. It is, however, contrary to both the substance and spirit of the democratic peace proposition to wage war in the name of democracy. As just mentioned, whether one can impose democracy from outside is a topic that scholars have already started to study. ${ }^{37}$ Whether one should is a different but equally important topic. It should be recalled that Immanuel Kant, the intellectual predecessor acknowledged by most liberal internationalists writing about the democratic peace proposition, envisioned like-minded political entities voluntarily joining a pacific league of autonomous members. Spreading democracy at the point of bayonets would be the farthest from his thinking.

\section{Conclusion}

The democratic peace proposition has been the focus of an impressive amount of research, much of which presenting evidence in support of at least the dyadic version of this proposition, namely, that democracies do not fight each other. This essay addresses mostly the monadic version of this proposition, raising a number of issues about whether democracies are more peaceful in general, that is, even when they are paired with autocracies in international interactions. The suggestions offered in this essay are intended to further advance the research agenda investigating the effects of regime characteristics on a country's bellicosity or pacifism in international relations. It has been deliberately provocative, but its purpose is to encourage further clarification and extension of this important area of research. It points out several areas pertaining to concept formation, methodological application, and causal attribution where greater clarity and care can be beneficial. Moreover, it warns against the potential misuse of this proposition for policy purposes or public justification in ways that are contrary to the spirit motivating it in the first place.

\section{Notes}

Steve Chan is Professor of Political Science at the University of Colorado, Boulder, U.S.A. He may be reached at steve.chan@colorado.edu. This is a revised version of a keynote address presented at Second Australasian Conference on Economics and Politics of War and Peace, 25-26 July 2008, Macquarie University, Sydney, Australia.

1. Levy (1989, p. 270).
2. Russett (1990, p. 123).

3. See, for example, Doyle (1983a, 1983b, 1986, 2005). For an outstanding empirical analysis, see Russett and Oneal (2001).

\section{Kant (1795).}

5. There are many strands of realism. Waltz (1979) offers the most prominent neorealist statement. For examples of realist work that challenges the democratic peace proposition, see Layne (1994) and Rosato (2005).

6. For literature reviews on this topic, see Rummel (1985); Morgan (1993); Maoz (1998); Ray (1998); Russett and Starr (2000); MacMillan (2000); Morrow (2002); Chan (1997, 2008).

7. Kant (1795).

8. Besides Doyle’s articles, see Huntley (1996).

9. Rummel (1979, 1981, 1983).

10. Ray (1993).

11. Reiter and Tillman (2002).

12. Vanhanen (2000).

13. For instance, Gates, Hegre, Jones and Strand (2006) developed a Scalar Index of Politics (SIP) based on measures from both the Polity and Vanhanen datasets.

14. On democratic intervention, see Kegley and Hermann $(1995,1996)$ and Hermann and Kegley (1996).

15. The monadic version of the democratic peace proposition claims that democracies are more peaceful in general - that is, their peaceful disposition is not affected by the regime characteristic of the other party in a relationship, whether it is also a democracy or an autocracy. The dyadic version only claims that democracies are more peaceful toward each other.

16. See www.visionofhumanity.org [accessed 1 September 2008].

17. Peceny, Beer, and Sanchez-Terry (2002). 
18. Farber and Gowa (1995, 1997); Gartzke (2007); Gibler (2007). A review of the hypothesis that it is not democracies but international trade that contributes to peace, see, e.g., Polachek (2007).

19. Thompson (1996); Gleditsch (2002).

20. Ward, Siversion, and Cao (2007).

\section{Morrow (2002).}

22. Fearon (1994a, 1994b, 1995) developed the idea of audience costs, and Gaubatz (1999) offered a persuasive analysis on electoral incentives and democracies’ wars.

23. Bueno de Mesquita, Siverson, and Woller (1992) and Bueno de Mesquita and Siverson (1995) showed that democratic leaders' political tenure is likely to be shortened if they suffer defeat in war.

24. Schulz (1999, 2001a, 2001b) is especially pertinent in this regard.

25. For pertinent discussions, see Kaufman (2004, 2005) and Howell and Pevehouse (2007).

26. Reiter and Tillman (2002); Leblang and Chan (2003); Ireland and Palmer (2004); Palmer, London, and Regan (2004).

27. The term "selectorate” was used by Bueno de Mesquita, Morrow, Siversion, and Smith (1999), and Bueno de Mesquita, Smith, Sivreson, and Morrow (2003) to develop this line of argument.

\section{See Weeks (2008).}

29. Maoz and Russett (1993) presented normative and structural explanations of democratic peace.

30. See Mueller (1973) for a classic study on this topic, and Gelpi, Feaver, and Reifler (2008, 2005/06) and Berinsky (2007) for the more recent debate.

31. Jentleson (1992); Jentleson and Britton (1998); Eichenberg (2005).

32. See Chan and Safran (2006).
33. Bueno de Mesquita and Lalman (1992) and Maoz and Russett (1993), for example, recognized that democracies can wage war against autocracies. Schweller (1992) argued that democracies are unlikely to start preventive war unless under exceptional circumstances.

34. See, for example, Meernik (1996); Peceny (1999); Pickering and Kisangani (2006); Pickering and Peceny (2006).

35. Paris (2004)

36. Levy and Gochal (2001); Ripsman and Levy (2007); Silverstone (2007); Levy (2008); Trachtenberg (2008).

37. In addition to the studies already cited, see Bueno de Mesquita and Downs (2006) with particular relevance for the ongoing Iraq war.

\section{References}

Berinsky, A. 2007. “Assuming the Costs of War: Events, Elites, and American Public Support for Military Conflict.” Journal of Politics, Vol. 69, No. 4, pp. 975-997.

Bueno de Mesquita, B. and G.W. Downs. 2006. "Intervention and Democracy." International Organization, Vol. 60, No. 3, pp. 627-649.

Bueno de Mesquita, B. and D. Lalman. 1992. War and Reason: Domestic and International Imperatives. New Haven, CT: Yale University Press.

Bueno de Mesquita, B., J.D. Morrow, R.M. Siverson, and A. Smith. 1999. “An Institutional Explanation of the Democratic Peace.” American Political Science Review, Vol. 93, No. 4, pp. 791-807.

Bueno de Mesquita, B. and R.M. Siverson. 1995. "War and the Survival of Leaders: A Comparative Study of Regime Types and Political Accountability.” American Political Science Review, Vol. 89, No. 4, pp. 841-855.

Bueno de Mesquita, B., R.M. Siverson, and G. Woller. 1992. "War and the Fate of Regimes: A Comparative Analysis.” American Political Science Review, Vol. 86, No. 3, pp. 638-646.

Bueno de Mesquita, B., A. Smith, R.M. Siversion, and J.D. Morrow. 2003. The Logic of Political Survival. Cambridge, MA: The MIT Press.

Chan, S. 1997. "In Search of Democratic Peace: Problems and Promises.” Mershon International Studies Review, Vol. 41, No. 1, pp. 59-91.

Chan, S. 2008. "Progress in the Democratic Peace Research Agenda.” Mimeo. Boulder: University of Colorado.

Chan, S. and W. Safran. 2006. "Public Opinion as a Constraint against War: Democracies’ Responses to Operation Iraqi Freedom.” Foreign Policy Analysis, Vol. 2, pp. 137-156. 
Doyle, M.W. 1983a. "Kant, Liberal Legacies, and Foreign Affairs: Part 1." Philosophy and Public Affairs, Vol. 12, No. 3, pp. 205-235.

Doyle, M.W. 1983b. "Kant, Liberal Legacies, and Foreign Affairs: Part 2." Philosophy and Public Affairs, Vol. 12, No. 4, pp. 323-353.

Doyle, M.W. 1986. "Liberalism and World Politics.” American Political Science Review, Vol. 80, No. 4, pp. 1151-1169.

Doyle, M.W. 2005. “Three Pillars of the Liberal Peace.” American Political Science Review, Vol. 99, No. 3, pp. 463-466.

Eichenberg, R.C. 2005. "Victory Has Many Friends: U.S. Public Opinion and the Use of Military Force.” International Security, Vol. 30, No. 2, pp. 140-177.

Farber, H.S. and J. Gowa. 1995. “Polities and Peace.” International Security, Vol. 20, No. 2, pp. 123-146.

Farber, H.S. and J. Gowa. 1997. “Common Interests or Common Politics?” Journal of Politics, Vol. 59, No. 2, pp. 393-417.

Fearon, J.D. 1994a. "Domestic Political Audiences and the Escalation of International Disputes.” American Political Science Review, Vol. 88, No. 3, pp. 577-594.

Fearon, J.D. 1994b. "Signaling Versus the Balance of Power and Interests: An Empirical Test of a Crisis Bargaining Model.” Journal of Conflict Resolution, Vol. 38, No. 2, pp. 236-269.

Fearon, J.D. 1995. "Rationalist Explanations of War.” International Organization, Vol. 49, No. 3, pp. 379-414.

Gartzke, E. 2007. “The Capitalist Peace.” American Journal of Political Science, Vol. 51, No. 1, pp. 166-191.

Gates, S., H. Hegre, M.P. Jones, and H. Strand. 2006. "Institutional Inconsistency and Political Instability: Polity Duration, 1800-2000.” American Journal of Political Science, Vol. 50, No. 4, pp. 893-908.

Gaubatz, K.T. 1999. Elections and War: The Electoral Incentive in the Democratic Politics of War and Peace. Stanford, CA: Stanford University Press.

Gelpi, C.F., P. Feaver, and J. Reifler. 2005/06. “Success Matters: Casualty Sensitivity and the War in Iraq.” International Security, Vol. 30, No. 3, pp. 7-46.

Gelpi, C.F., P. Feaver, and J. Reifler. 2008. Paying the Human Costs of War American Public Opinion and Casualties in Military Conflicts. Princeton, NJ: Princeton University Press.

Gibler, D.M. 2007. "Bordering on Peace: Democracy, Territorial Issues, and Conflict.” International Studies Quarterly, Vol. 51, No. 3, pp. 509-532.

Gleditsch, K.S. 2002. All Politics Is Local: The Diffusion of Conflict, Integration, and Democratization. Ann Arbor: University of Michigan Press.

Global Peace Index: 2008 Methodology, Results \& Findings. New South Wales, Australia. www.visionofhumanity.org.

Hermann, M.G. and C.W. Kegley, Jr. 1996. "Ballots, A Barrier against the Use of Bullets and Bombs: Democratization and Military Intervention.” Journal of Conflict Resolution, Vol. 40, No. 3, pp. 436-459.
Howell, W.G. and J.C. Pevehouse. 2007. While Dangers Gather: Congressional Check on Presidential War Powers. Princeton, NJ: Princeton University Press.

Huntley, W. 1996 "Kant's Third Image: Systematic Sources of the Liberal Peace.” International Studies Quarterly, Vol. 40, No. 1, pp. 45-76.

Ireland, M.J. and S.S. Gartner. 2001. "Time to Fight: Government Type and Conflict Initiation in Parliamentary Systems.” Journal of Conflict Resolution, Vol. 21, No. 2, pp. 547-568.

Jentleson, Bruce W. 1992. “The Pretty Prudent Public: Post-Vietnam American Opinion on the Use of Military Force.” International Studies Quarterly, Vol. 36, No. 1, pp. 47-74

Jentleson, B.W. and R.L. Britton. 1998. "Still Pretty Prudent: Post-Cold War American Public Opinion on the Use of Military Force.” Journal of Conflict Resolution, Vol. 42, No. 4, pp. 395-417.

Kant, I. 1795 (1957). Perpetual Peace. Translated by L.W. Beck. New York: Bobbs-Merrill.

Kaufman, C. 2004 "Threat Inflation and the Failure of the Marketplace of Ideas: The Selling of the Iraq War.” International Security, Vol. 29, No. 1, pp. 5-48.

Kaufman, C. 2005. "Selling the Market Short: The Marketplace of Ideas and the Iraq War.” International Security, Vol. 29, No. 4, pp. 196-207.

Kegley Jr., C.W. and M. Hermann. 1995. "Military Intervention and the Democratic Peace.” International Interactions, Vol. 21, No. 1, pp. 1-21.

Kegley Jr., C.W. and M. Hermann. 1996. "How Democracies Use Intervention: A Neglected Dimension in Studies of the Democratic Peace.” Journal of Peace Research, Vol. 33, No. 3, pp. 309-322.

Layne, C. 1994. "Kant or Cant: The Myth of Democratic Peace.” International Security, Vol. 19, No. 2, pp. 5-49.

Leblang, D. and S. Chan. 2003. "Explaining Wars Fought by Established Democracies: Do Institutional Constraints Matter?” Political Research Quarterly, Vol. 56, No. 4, pp. 385-400.

Levy, J.S. 1989. “The Causes of War: A Review of Theories and Evidence,” pp 209-333 in P.E. Tetlock, J.L. Husbands, R. Jervis, P.C. Stern, and C. Tilly, eds. Behavior, Society, and Nuclear War. New York: Oxford University Press.

Levy, J.S. 2008. "Preventive War and Democratic Politics.” International Studies Quarterly, Vol. 52, No. 1, pp. 1-24.

Levy, J.S. and J.R. Gochal. 2001. "Democracy and Preventive War: Israel and the 1956 Sinai Campaign.” Security Studies, Vol. 11, No. 2, pp. 1-49.

MacMillan, J. 2003. "Beyond the Separate Democratic Peace.” Journal of Peace Research, Vol. 40, No. 2, pp. 233-243.

Maoz, Z. 1998. "Realist and Cultural Critiques of the Democratic Peace." International Interactions, Vol. 24, No. 1, pp. 1-89.

Maoz, Z. and B.M. Russett. 1993. "Normative and Structural Causes of Democratic Peace, 1946-1986.” American Political Science Review, Vol. 87, No. 3, pp. 
624-638.

Meernik, J. 1996. "U.S. Military Interventions and the Promotion of Democracy." Journal of Peace Research, Vol. 33, No. 4, pp. 391-402.

Morgan, C.T. 1993. "Democracies and War: Reflections on the Literature." International Interactions, Vol. 18, No. 3, pp. 197-203.

Morrow, J.D. 2002. "Understanding International Conflict: Microfoundations, the Democratic Peace, and Offense-Defense Theory,” pp. 172-196 in I. Katznelson and H.V. Milner, eds. Political Science: The State of the Discipline. New York: Norton.

Mueller, J.E. 1973. War, Presidents, and Public Opinion. New York: Wiley.

Palmer, G.G., R.R. London, and P.M. Regan. 2004. "What's Stopping You? The Sources of Political Constraints on International Conflict Behavior in Parliamentary Democracies.” International Interactions, Vol. 30, No. 1, pp. 1-24.

Paris, R. 2004. At War's End: Building Peace After Civil Conflict. Cambridge: Cambridge University Press.

Peceny, M. 1999. Democracy at the Point of Bayonets. University Park, PA: Pennsylvania State University Press.

Peceny, M., C. Beer, and S. Sanchez-Terry. 2002. “Dictatorial Peace?” American Political Science Review, Vol. 96, No. 1, pp. 15-26.

Pickering, J. and E. Kisangani. 2006. "Political, Economic, and Social Consequences of Foreign Intervention.” Political Research Quarterly, Vol. 59, No. 3, pp. 363-37.

Pickering, J. and M. Peceny. 2006. “Forging Democracy at Gunpoint.” International Studies Quarterly, Vol. 50, No. 3, pp. 539-560.

Polachek, S.W. "How Trade Affects International Interactions.” Economics of Peace and Security Journal, Vol. 2, No. 2 (2007), pp. 60-68.

Ray, J.L. 1993. “War Between Democracies: Rare, or Nonexistent?” International Interactions, Vol. 18, No. 3, pp. 251-276

Ray, J.L. 1998. “Does Democracy Cause Peace?” Annual Review of Political Science, Vol. 1, pp. 27-46.

Reiter, D. and E.R. Tillman. 2002. "Public, Legislative, and Executive Constraints on the Democratic Initiation of Conflict.” Journal of Politics, Vol. 64, No. 3, pp. 810-826.

Ripsman, N.M. and J.S. Levy. 2007. "The Preventive War that Never Happened: Britain, France, and the Rise of Germany in the 1930s.” Security Studies, Vol. 16, No. 1, pp. 32-67.

Rosato, S. 2003. "The Flawed Logic of Democratic Peace Theory.” American Political Science Review, Vol. 97, No. 4, pp. 585-602.

Rummel, R.J. 1979. War, Power, Peace. Beverly Hills, CA: Sage.

Rummel, R.J. 1981. The Just Peace. Beverly Hills, CA: Sage.

Rummel, R.J. 1983. “Libertarianism and International Violence.” Journal of Conflict Resolution, Vol. 27, No. 1, pp. 27-71.
Rummel, R.J. 1985. "Libertarian Propositions on Violence Within and Between Nations: A Test Against Published Research Results.” Journal of Conflict Resolution, Vol. 29, No. 3, pp. 419-455.

Russett, B.M. 1990. Controlling the Sword: The Democratic Governance of National Security. Cambridge, MA: Harvard University Press.

Russett, B.M. and J.R. Oneal. 2001. Triangulating Peace: Democracy, Interdependence, and International Organizations. New York: Norton.

Russett, B.M. and H. Starr. 2000. "From Democratic Peace to Kantian Peace: Democracy and Conflict in the International System,” pp. 93-128 in M.I. Midlarsky, ed. Handbook of War Studies, Vol. II. Ann Arbor: University of Michigan Press.

Schultz, K.A. 1999. "Do Democratic Institutions Constrain or Inform? Contrasting Two Institutional Perspectives on Democracy and War." International Organization, Vol. 53, No. 2, pp. 233-266.

Schultz, K.A. 2001a. "Looking for Audience Costs.” Journal of Conflict Resolution, Vol. 45, No. 1, pp. 32-60.

Schultz, K.A. 2001b. Democracy and Coercive Diplomacy. Cambridge: Cambridge University Press.

Schweller, R.L. 1992. "Domestic Structure and Preventive War: Are Democracies More Pacific?” World Politics, Vol. 44, No. 2, pp. 235-269.

Silverstone, S.A. 2007. Preventive War and American Democracy. London: Routledge.

Thompson, W. 1996. “Democracy and Peace: Putting the Cart Before the Horse?” International Organization, Vol. 50, No. 1, pp. 141-174

Trachtenberg, M. 2007. "Preventive War and U.S. Foreign Policy.” Security Studies, Vol. 16, No. 1, pp. 1-31.

Vanhanen, T. 2000. “A New Dataset for Measuring Democracy, 1810-1998.” Journal of Peace Research, Vol. 37, No. 2, pp. 251-265

Waltz, K.N. 1979. Theory of International Politics. Reading, MA: Addison-Wesley.

Ward, M.D., R.M. Siverson, and X. Cao. 2007. "Disputes, Democracies, and Dependencies: A Reexamination of the Kantian Peace.” American Journal of Political Science, Vol. 51, No. 3, pp. 583-601.

Weeks, J. 2008. “Autocratic Audience Costs: Regime Type and Signaling Resolve.” International Organization, Vol. 62, No. 1, pp. 35-64. 